\title{
Vulnerability of Zimbabwe forests to global climate change
}

\author{
C. H. Matarira, F. C. Mwamuka \\ Scientific and Industrial Research and Development Centre (SIRDC), Environment and Remote Sensing Institute (ERSI), \\ PO Box 6640, Harare, Zimbabwe
}

\begin{abstract}
The impacts of global climate change on forest distribution was evaluated using the Holdridge life zone and GISS general circulation model scenarios. Across Zimbabwe, 17 to $18 \%$ of the total land area is projected to shift from subtropical thorn woodland and subtropical dry forest to tropical very dry forest under the GISS scenario. The projected shift in forest distribution is attributable to a future decline in precipitation patterns and an increase in ambient temperature.
\end{abstract}

KEY WORDS: Climate models - Ecological zone Forestry

\section{INTRODUCTION}

Anthropogenic emissions of greenhouse gases (e.g. $\mathrm{CO}_{2}, \mathrm{CH}_{4}$ ) to the atmosphere are projected to stimulate global climate change (Houghton et al. 1992). Shifts in the distribution of global vegetation, especially forest systems, may result from changes in ambient temperature and precipitation patterns (Smith et al. 1993). Extratropical forest biomes are expected to shift poleward, while low latitude forests could expand or contract regionally (Prentice et al, 1992).

The forest systems of Zimbabwe vary in distribution and productivity (Singh 1993). Forests offer both timber and non-timber goods and services in spite of recent degradation and loss of indigenous species. Plantations composed of exotic species are widespread, providing an adequate supply of wood and fiber products. Both indigenous and exotic forest species are highly susceptible to short-term shifts in climate (Smith et al. 1991). The objective of this study is to compare the current and future distribution of forest resources in Zimbabwe using Holdridge life zone classification and a General Circulation Model (GCM) scenario.

\section{MATERIALS AND METHODS}

The scenario of double $\mathrm{CO}_{2}$ climate change used to drive the GCM was the Goddard Institute of Space
Studies (GISS) model (Hansen et al. 1983). The output from the model was precipitation and surface air temperature data. One of the limitations of the GCM is spatial resolution. Zimbabwe in this case study is represented by 4 grid points which cannot fully represent the high spatial precipiation variability across the country due to the influence of topographic differences and other factors. A north-south and east-west gradient exists in precipitation and ambient temperature patterns which is not fully represented by the 4 grid points over Zimbabwe (Unganai 1996).

The potential effects of global climate change on the forests of Zimbabwe were estimated using the GISS scenario and the Holdridge Life Zone classification (Holdridge 1967, Smith et al. 1993). The Holdridge classification relates the major plant formations in the world to 2 climate variables, biotemperature (growing season index) and total annual precipitation. The Holdridge life zones considered in this study of Zimbabwe include 5 classifications (Table 1). The future vegetation scenario should be considered as a sensitivity analysis given the limitations of both GCMs and the Holdridge system (Smith et al. 1991).

\section{RESULTS}

Under current climate conditions Zimbabwe contains 5 Holdridge life zones: subtropical dry forest, 
Table 1. Holdridge forest life zone classes for Zimbabwe under current climate conditions

\begin{tabular}{|lrc|}
\hline Life zone classes & $\begin{array}{c}\text { Forest area } \\
\left(\mathrm{km}^{2}\right)\end{array}$ & $\begin{array}{c}\% \text { of } \\
\text { Zimbabwe }\end{array}$ \\
\hline Subtropical dry forest & 264056 & 68.7 \\
Subtropical thorn woodland & 83725 & 21.8 \\
Tropical very dry forest & 21253 & 5.5 \\
Subtropical moist forest & 10304 & 2.8 \\
Warm temperate moist forest & 5152 & 1.2 \\
\hline
\end{tabular}

subtropical thorn woodland, tropical very dry forest, subtropical moist forest, and warm temperate moist forest (Table 1). The Holdridge life zone subtropical dry forest covers the largest area in Zimbabwe $68.7 \%$ by area) and extends across the largest latitudinal range, $15.5^{\circ} \mathrm{S}$ and $22^{\circ} \mathrm{S}$. This zone corresponds to miombo woodland and savanna, mopane woodland and savanna, Terminalia-Combretum woodland, Zambezi teak (Tectona grandis) woodland and Acacia woodland according to historic classification systems.

Under the GISS scenario there is a climate shift towards reduced annual precipitation and high ambient temperatures. Northeastern Zimbabwe, for example, becomes more suitable for vegetation found under the subtropical moist forest conditions in the GISS climate change scenario as opposed to the warm temperate moist forest which exists under current climate conditions (Table 2 ). Similarly, the southeastern region of Zimbabwe is projected to become unsuitable as a subtropical moist forest area and to shift to the subtropical dry forest life zone. The greatest life zone changes are those shifts from subtropical dry forest to tropical very dry forest and from subtropical thorn woodland to tropical very dry forest.

\section{DISCUSSION AND CONCLUSION}

Shifts in the areal distribution of Zimbabwe forests are predicted by the GISS climate change scenario and the Holdridge model (Smith et al. 1991). During this century, southern Africa has experienced dramatic fluctuations in precipitation, with significant impacts on agronomic and forest vegetation (Unganai 1996). Recent climate shifts in southern Africa have been sporadic, but future changes may be more distinctive in direction and magnitude (Houghton et al. 1992). The widely cultivated exotic forest species of Zimbabwe may be especially susceptible to shifts in precipitation and ambient temperature (Dixon et al. 1996).
Table 2. Holdridge torest life zone classes for Zimbabwe under GISS climate change scenario

\begin{tabular}{|lrc|}
\hline Life zone classes & $\begin{array}{c}\text { Forest area } \\
\left(\mathrm{km}^{2}\right)\end{array}$ & $\begin{array}{c}\% \text { of } \\
\text { Zimbabwe }\end{array}$ \\
\cline { 1 - 2 } Subtropical thorn woodland & 9016 & 2.3 \\
Subtropical dry forest & 175179 & 45.6 \\
Subtropical moist forest & 1223 & 3.2 \\
Tropical thorn woodland & 3220 & 0.8 \\
Tropical very dry forest & 157790 & 1.0 \\
Tropical dry forest & 27050 & 7.1 \\
\hline
\end{tabular}

The climate scenario comparisons in this study should be viewed as a sensitivity analysis due to limitations of the models and their high spatial variability (Smith et al. 1993). The Holdridge model is steadystate, not dynamic, and does not consider the ecologic and physiologic response of plants (Prentice et al. 1992). Although this analysis has limitations, it is a preliminary estimate of future forest system response to climate change in Zimbabwe.

Acknowledgement. This study was supported by the U.S. Country Studies Program.

\section{LITERATURE CITED}

Dixon RK, Perry JA, Vanderklein EL, Hiol Hiol F (1996) Vulnerability of forest resources to global climate change: case study of Cameroon and Ghana. Clim Res 6:127-133

Hansen F, Russell G, Rind D, Stone $P$, Lacis $A$, Lebedeff $S$, Ruedy $R_{1}$ Travis L (1983) Efficient three-dimensional global models for climate studies: models I and II. Mon Weather Rev 11:609-662

Holdridge LR (1967) Life zone ecology. Tropical Science Center, San Jose, CA

Houghton JT, Callendar B, Varney SK (eds) (1992) Climate change 1992: the IPCC supplementary report on the IPCC scientific assessment. Cambridge University Press, Cambridge

Prentice IC, Harrison SP, Leemans R, Monserud RA, Solomon AM (1992) A global biome model based on plant physiology and dominance, soil properties and climate. J Biogeogr 19:117-134

Singh KD (1993) Forest resources assessment 1990: tropical countries. FAO Forestry Paper 112. Food and Agriculture Organization of the United Nations, Rome

Smith TM, Cramer WP, Dixon RK, Leemans R, Neilson RP, Solomon AM (1993) The global terrestrial carbon cycle. Water Air Soil Pollut 70:19-38

Smith TM, Shugart HH, Bonan GB, Smith JB (1991) Modelling the potential response of vegetation to global climate change. Adv Ecol Res 22:93-116

Unganai LS (1996) Historic and future climatic change in Zimbabwe. Clim Res 6:137-145 